\title{
"Não deixem a tinta coagular em suas canetas": por uma escrita orgânica
}

\author{
"Do not let the ink coagulate in your pens": in favor of an organic writing \\ Susel Oliveira da Rosa \\ https://orcid.org/0000-0003-2388-4454 \\ Universidade Estadual da Paraíba
}

\begin{abstract}
Resumo: Nesse artigo me proponho a exercitar uma "escrita orgânica", aceitando o convite de Glória Anzaldúa (2000). Com base em minha experiência com minha mãe e Dona Leonor, busco minimamente, perceber o funcionamento do dispositivo da racialidade, tal como Sueli Carneiro (2005) desenvolve. Tendo em mente a responsabilidade em criar novas configurações de poder e de conhecimento, como enfatiza Grada Kilomba (2019), também sugiro a possibilidade de estabelecermos um lugar de escuta a partir da compreensão efetiva do que é lugar de fala, via Djamila Ribeiro (2017).
\end{abstract}

Palavras-chave: Dispositivo da racialidade. Epistemicídio. Experiência.

Abstract: In this article, I propose the exercise of an "organic writing", accepting the invitation of Glória Anzaldúa (2000). Based on my experience with my mother and Ms. Leonor, I seek to minimally perceive the functioning of the racial device, much like Sueli Carneiro (2005) develops. Having in mind the responsibility to create new power and knowledge configurations, as Grada Kilomba (2019) highlights, I also highlight the possibility of establishing a place of hearing from the effective comprehension of what is locus of speech, via Djamila Ribeiro (2017).

Keywords: Racial device. Epistemicide. Experience.

Não deixem que a caneta lhes afugente de vocês mesmas. Não deixem a tinta coagular em suas canetas. Não deixem o censor apagar as centelhas, nem mordaças abafar suas vozes. Ponham suas tripas no papel [...] eles mentiram, não existe separação entre vida e escrita (Anzaldúa, 2000, p.233-235).

Em sua "Carta para as mulheres escritoras do terceiro mundo" - redigida nos últimos dias do mês de maio de 1980 -, Gloria Anzaldúa convida a não separarmos a escrita da vida, a usarmos o que nos é significativo como matéria de nossa escrita. "Mesmo se estivermos famintas, não somos pobres de experiências", escrevia ela. Gloria Anzaldúa é chicana, filha de imigrantes mexicanos, nascida no Texas. Uma mestiça que teve sua família separada pela fronteira (fronteira que marcou a sua vida, pois morava bem próxima da que separa dois países - México e EUA - e, com eles, seus parentes). Anzaldúa cresceu trabalhando nas plantações (aproveitava para ler nos intervalos de descanso). Desde 1950 participou da luta dos camponeses, atuando na resistência já muito jovem. Teve contato com os feminismos nos fins dos anos $1960 \mathrm{e}$ nos anos 1970 passou a produzir literariamente (romances, contos, poemas, autobiografias). A partir de então, passou a lutar para que as mulheres de cor (não 
brancas) conquistassem espaço, produzindo teoricamente e não apenas sendo objeto de estudo. Anzaldúa convidou-nos a repensar as fronteiras, a partir do olhar dos que habitam essas fronteiras, esses entre-lugares mestiços:

Como mestiza, eu não tenho país, minha terra natal me despejou; no entanto, todos os países são meus porque eu sou a irmã ou a amante em potencial de todas as mulheres. (Como uma lésbica não tenho raça, meu próprio povo me rejeita; mas sou de todas as raças porque a queer em mim existe em todas as raças.) Sou sem cultura porque, como uma feminista, desafio as crenças culturais/religiosas coletivas de origem masculina dos indo-hispânicos e anglos; entretanto, tenho cultura porque estou participando da criação de uma outra cultura, uma nova história para explicar o mundo e a nossa participação nele, um novo sistema de valores com imagens e símbolos que nos conectam um/a ao/à outro/a e ao planeta. Soy un amasamiento, sou um ato de juntar e unir que não apenas produz uma criatura tanto da luz como da escuridão, mas também uma criatura que questiona as definições de luz e de escuro e dá-Ihes novos significados. (Anzaldúa, 2005, p.707-708)

Entre-lugares que marcam a trajetória de muitas mulheres, quiçá da maioria delas. Fronteiras de região, de sexo, de gênero, de etnia, de classe. Nos últimos meses (entre o final de 2018 e o primeiro semestre de 2019), ao me propor pensar o lugar interseccional de algumas dessas mulheres, não-brancas, de descendência indígena ou afro-brasileira, a partir dos feminismos negros e mestiços, me deparei com minha própria história através da história de minha mãe e, especialmente, da história de "Dona Leonor". Nesse sentido, proponho nesse artigo não apenas o investimento numa reflexão que contemple a experiência, como sugere Didi-Huberman (2011), ao retomar Walter Benjamin (1994), mas aceito o convite de Anzaldúa e tento guiar-me por uma "escrita orgânica"- "não é no papel que você cria, mas no seu interior, nas vísceras e nos tecidos vivos, chamo isto de escrita orgânica" (2000, p. 234) - ao retomar aqui, minhas próprias lembranças da infância e adolescência. Elas me acompanharam ao ler Carla Akotirene (2018) e Djamila Ribeiro (2017) e, delas, retomar Glória Anzaldúa (2000, 2005) e seguir para Grada Kilomba (2019) e Sueli Carneiro (2005), que forneceram o aporte teórico e epistêmico para esse artigo.

\section{Minha mãe}

Lembro de ouvir de minha mãe, desde muito cedo, o quanto ela gostaria que sua pele fosse mais clara, como a minha. Lembro de um gesto que ela fazia algumas vezes, ao me dizer isso, como que esfregando a pele de seu próprio braço. Ainda criança, eu ficava assustada com esse gesto e não entendia porque ela desejaria raspar sua própria pele. Sempre achei a pele de minha mãe mais bonita que a minha. Mais bonita que a de meu pai, que era descendente de alemães. Lembro também de ouvir minhas tias as irmãs de minha mãe - se referirem a ela como "a negra", "aquela negra", "lá vem a negra Enar". Algumas vezes em tom agressivo, outras em tom condescendente. Lembro de minha mãe colocando "rolos" no cabelo, para cachear seus crespos, pois sempre reclamou muito de seu cabelo também. Lembro, nitidamente, de quando ouvi dela que quando era criança, depois de repetir três vezes a primeira série do ensino fundamental, foi retirada da escola e colocada para cozinhar. "Essa negra é burra, não aprende, só serve para cozinhar", escutava de seus pais, meus avós. Cozinhava - ou ajudava minha avó na cozinha - para três irmãos, sete irmãs, o pai e a mãe. Nessa condição, era sempre a última das irmãs a receber um calçado novo ou um novo vestido de "saco de estopa", já que seu lugar era a cozinha. Nos três anos que frequentou a escola, 
apanhava de "palmatória", pois além de "mais escura", nascera "canhota". Apanhava para aprender a escrever com a mão direita. Algo que ela nunca conseguiu. Conseguiu, anos mais tarde, ensinar a filha, que nasceu canhota como ela, a não usar a mão esquerda. Não queria que eu apanhasse como ela, nem fosse canhota, como ela. Lembro também quando me contou que a família de meu pai, especialmente minha avó paterna, rejeitou o casamento do filho com "uma negra". Minha mãe só teve direito a entrar na casa da sogra depois que seus filhos nasceram. Meu irmão e eu, nascidos da "negra", foram o passaporte para a presença dela naquela família.

Em sua já citada "Carta para mulheres escritoras do terceiro mundo", Anzaldúa parece reproduzir o que minha mãe ouvia:

O homem branco diz: Talvez se rasparem o moreno de suas faces. Talvez se branquearem seus ossos. Parem de falar em línguas, parem de escrever com a mão esquerda. Não cultivem suas peles coloridas, nem suas línguas de fogo se quiserem prosperar em um mundo destro. (Anzaldúa, 2000, p. 230)

Mundo destro que estabeleceu uma hierarquia dentro da negritude, "hierarquia que serve à construção da branquitude como a condição humana ideal", mostra Grada Kilomba, ao enfatizar que na língua portuguesa "nos deparamos quase com a ausência de um termo que não esteja ancorado à terminologia colonial nem à linguagem racista comum ou a uma nomenclatura animal" (Kilomba, 2019, p. 18-19). Quando fala em nomenclatura animal, a autora faz referência aos termos "mulata/o, mestiço/a, cabrito/a". Os dois primeiros remetem a cruzamentos de animais diferentes (mestiço remete ao cruzamento de cães de raças diferentes; mulato que remete ao cruzamento de um cavalo e uma mula), que resultam num terceiro animal, impuro e inferior. Todas as três palavras são "comumente usadas para definir as pessoas de pele mais clara, quase próximas da branquitude, sublinhando, porém, sua negritude, e definindo-as como animais" (p. 19-20). Animais não humanos, não dignos de pertencer a bios, a vida politicamente qualificada, como diria Giorgio Agamben (2004). Aqueles que se pode deixar morrer, como explicou Michel Foucault (2008) ao analisar o funcionamento da política, transformada em biopolítica:

Em março de 1976, durante uma aula no Collège de France, Michel Foucault falava a seus alunos sobre como a guerra havia sido retomada na forma de racismo de Estado. Racismo de Estado possibilitado pela assunção da vida pelo poder, pela tomada de poder sobre o homem enquanto ser vivo. Retomando a teoria clássica da soberania, Foucault lembrava que o soberano detinha o poder de vida e morte de seus súditos, poder de fazer morrer e deixar viver. Ao decretar a morte dos súditos, o soberano exercia, também, o poder sobre a vida - Foucault referia-se ao direito político soberano que vigorou até o século XIX, século em que o poder soberano foi perpassado e modificado por um poder inverso: o poder de fazer viver e deixar morrer. Tratava-se da assunção da vida pelo poder, da biopolítica como denominou Foucault. (Rosa, 2007, p. 02)

Biopolítica, racismo de estado, vida que se pode deixar morrer. Sueli Carneiro retoma as reflexões de Foucault, enfatizando a permanência do racismo - esse que tece o corte biológico na espécie humana -, no que ela vai denominar de "dispositivo da racialidade" (Carneiro, 2005). Se Michel Foucault (2001) mostrou como passamos do dispositivo de aliança ao dispositivo da sexualidade, Sueli Carneiro mostra como o dispositivo da sexualidade se imbrica ao "dispositivo da racialidade":

Perseguindo essa trilha aberta por Foucault sobre a estratégia de afirmação da 
burguesia enquanto classe hegemônica, parece-nos, em uma primeira análise, que o processo de auto-afirmação de classe foi acompanhado, para além da constituição do dispositivo de sexualidade, pela emergência ou operação do dispositivo de racialidade, no qual a cor da pele irá adquirir um novo estatuto. Há, portanto, um não-dito na formulação de Foucault que é a imbricação do dispositivo de sexualidade com o de racialidade, abrangendo este um território mais vasto do que o de sexualidade, pelo estatuto que tem nele a cor da pele. (Carneiro, 2005, p. 44)

Dispositivo da racialidade que transforma a biopolítica cada vez mais em "necropolítica" (Mbembe, 2018). Se a vitalidade está para a branquitude, a morte está para a negritude. Nesse sentido, a autora demonstra, em sua tese de doutoramento, como o que denomina de dispositivo da racialidade estruturou e estrutura as relações no Brasil. Dispositivo da racialidade que, apoiado em um de seus elementos constitutivos, o epistemicídio ${ }^{1}$, consolida as hierarquias raciais produzidas pelo próprio dispositivo (Carneiro, 2005, p.33). Sueli Carneiro também retoma Hannah Arendt, pois esta última acreditava que "foi a ideologia racial, e não a de classes, que acompanhou o desenvolvimento da comunidade das nações europeias, até se transformar em arma que destruiria essas nações" (Carneiro, 2005, p. 51 apud Arendt, 1989, p. 191). Ideologia racial, dispositivo da racialidade, epistemicídio: todos imbricados na produção das vidas que se pode deixar morrer, das vidas descartáveis, das vidas nuas no horizonte de um neoliberalismo, que permanece ancorado e atualizando o colonialismo. Vale lembrar que ao atualizar a noção de epistemicídio e situá-lo como um dos elementos do dispositivo da racialidade, Sueli Carneiro assim o define:

Para nós, porém, o epistemicídio é, para além da anulação e desqualificação do conhecimento dos povos subjugados, um processo persistente de produção da indigência cultural: pela negação ao acesso a educação, sobretudo de qualidade; pela produção da inferiorização intelectual; pelos diferentes mecanismos de deslegitimação do negro como portador e produtor de conhecimento e de rebaixamento da capacidade cognitiva pela carência material e/ou pelo comprometimento da auto-estima pelos processos de discriminação correntes no processo educativo. Isto porque não é possível desqualificar as formas de conhecimento dos povos dominados sem desqualificá-los também, individual e coletivamente, como sujeitos cognoscentes. E, ao fazê-lo, destitui-lhe a razão, a condição para alcançar o conhecimento "legítimo" ou legitimado. Por isso o epistemicídio fere de morte a racionalidade do subjugado ou a sequestra, mutila a capacidade de aprender etc. É uma forma de sequestro da razão em duplo sentido: pela negação da racionalidade do Outro ou pela assimilação cultural que em outros casos lhe é imposta.

Sendo, pois, um processo persistente de produção da inferioridade intelectual ou da negação da possibilidade de realizar as capacidades intelectuais, o epistemicídio nas suas vinculações com as racialidades realiza, sobre seres humanos instituídos como diferentes e inferiores constitui, uma tecnologia que integra o dispositivo de racialidade/biopoder, e que tem por característica específica compartilhar características tanto do dispositivo quanto do biopoder, a saber, disciplinar/

\footnotetext{
${ }^{1}$ Carneiro parte e atualiza a noção de Boaventura Santos (1997), sobre o epistemicídio: "o genocídio que pontuou tantas vezes a expansão européia foi também um epistemicídio: eliminaram-se povos estranhos porque tinham formas de conhecimento estranho e eliminaram-se formas de conhecimento estranho porque eram sustentadas por práticas sociais e povos estranhos. Mas o epistemicídio foi muito mais vasto que o genocídio porque ocorreu sempre que se pretendeu subalternizar, subordinar, marginalizar, ou ilegalizar práticas e grupos sociais que podiam ameaçar a expansão capitalista ou, durante boa parte do nosso século, a expansão comunista (neste domínio tão moderno quanto a capitalista); e também porque ocorreu tanto no espaço periférico, extra-europeu e extra-norte-americano do sistema mundial, como no espaço central europeu e norte-americano, contra os trabalhadores, os índios, os negros, as mulheres e as minorias em geral (étnicas, religiosas, sexuais)" (Carneiro, 2005, apud Santos, 1995, p. 328).
} 
normalizar e matar ou anular. É um elo de ligação que não mais se destina ao corpo individual e coletivo, mas ao controle de mentes e corações. (Carneiro, 2005, p. 97-98)

Ao ferir de morte ou sequestrar a racionalidade de quem é subjugado, nega a voz a todos que são descartáveis em sua lógica. Produz, assim, o silêncio que acompanhou a vida de Dona Leonor, ela que também foi deixada morrer - na falta de acesso a trabalho digno, a educação, a saúde - com sua família.

\section{Dona Leonor}

Dona Leonor, sua filha Vera e seu esposo - "Seu Ayres" - me intrigavam muito quando criança. Muitas tardes eu passava na casa de minha avó materna e, algumas vezes, lá aparecia dona Leonor, sempre muito silenciosa, sempre parecendo envergonhada, de cabeça baixa, que só levantava quando Ihe dirigiam a palavra. Levantava a cabeça timidamente, envergonhadamente. Eu observava muito aquela forma dela, de sua filha e de seu esposo se (des)fazerem entre nós. Os olhos grandes, quando, muito raramente nos olhavam, pareciam comunicar tanto em seu silêncio. Mas eu não conseguia entender. Não entendia porque agiam diferente das outras pessoas que conhecia.

Eu gostava muito de caminhar com minha mãe até a casa deles. A casa de minha avó já era simples, "pobre", como diziam. Mas a casa de dona Leonor era mais. Era uma casa menor e de "chão batido". Mas eu achava mais aconchegante, talvez porque fosse rodeada de plantas, talvez porque fosse de madeira, ou porque fosse colorida - por fora era pintada com um verde que me encantava. Talvez porque eu sentisse mais amorosidade e cuidado naquela família. A cozinha era tão pequena que sentávamos quase grudadas no fogão a lenha. Fogão que era usado para aquecer a casa e seus moradores nas épocas mais gélidas do inverno gaúcho. Todas nós morávamos em Santana do Livramento, uma cidade de fronteira, ao atravessar uma rua já estávamos na cidade de Rivera, Uruguai. Mas quero contar aqui do dia em que entendi porque Dona Leonor era tão silenciosa e andava sempre com a cabeça baixa e o olhar direcionado ao chão.

Numa das tardes na casa de minha avó, lá estava ela sentada no pátio com minhas tias, e as tias conversavam muito, eu devia estar brincando com algo - ou apenas acompanhava a conversa - quando ouvi minha mãe dizer: "isso é coisa de negro". Disse isso se referindo a algo ruim que uma pessoa tinha dito ou malfeito. Lembro que paralisei nessa hora, parece que ainda escuto essa frase pela primeira vez, vinda da boca de minha mãe e ainda consigo sentir a profunda vergonha que me tomou. O silêncio de Dona Leonor me atravessou e fiquei mais muda ainda do que já era. Não sei se tinha seis, sete, oito ou nove anos. Mas sei que foi nesse dia que entendi o que era racismo, sem saber que tinha esse nome. Penso que devo ter ouvido muitas vezes essa frase antes - de minha mãe, das vizinhas e vizinhos, de outras pessoas da família - mas desde então, ela sempre me paralisou. Foi naquele dia que entendi seu significado. Entendi como testemunha de segundo grau, como diriam os juristas - não como alguém que sofreu a ação, mas como alguém que presenciou a ação (Rosa e Silva, 2016). Entendi também o quanto pertencer ao mundo dos brancos - a branquitude - me colocava em um lugar de privilégio em relação aos negros. Algo mais aconteceu, a partir daquele dia: ao ler dona Leonor e sua família como negros, passei a não entender mais porque minha mãe se dizia e era chamada de negra. Graças ao 
feminismo negro, entendi, recentemente, a lógica do "colorismo" que coloca em diferentes lugares os de pele mais escura e os de pele mais clara. Assim também entendi o lugar de minha mãe nessa lógica. "Negra", mas de pele clara. "Morena, mulata, cabrita", como diria Grada Kilomba.

Grada Kilomba conta-nos que ao chegar em Berlin - onde cursou seu doutoramento que resultou no livro recentemente traduzido no Brasil como "Memórias da Plantação" -, vinda de Lisboa, cidade onde nasceu e vivera até então, percebeu que

tanto a história colonial alemã como a ditadura imperial fascista também deixaram marcas inimagináveis. $\mathrm{E}$, no entanto, pareceu-me haver uma pequena diferença: enquanto eu vinha de um lugar de negação, ou até mesmo de glorificação da história colonial, estava agora num outro lugar onde a história provocava culpa, ou até mesmo vergonha. Este percurso de conscientização coletiva, que começa com negação - culpa - vergonha - reconhecimento - reparação, não é de forma alguma um percurso moral, mas um percurso de responsabilização. A responsabilidade de criar novas configurações de poder e de conhecimento. (Kilomba, 2019, p. 11)

Essa responsabilidade de criar novas configurações de poder e de conhecimento é nossa, é toda nossa. Especialmente num país em que a negação ainda se faz muito presente e os caminhos do reconhecimento e, especialmente, da reparação, são ainda incipientes. Se não podemos barrar o genocídio podemos, de nossos lugares na academia - essa academia "que não é um espaço neutro nem tampouco simplesmente um espaço de conhecimento e sabedoria, de ciência e de erudição, é também um espaço de v-i-o-I-ê-n-c-i-a" (Kilomba, 2019, p. 51)² - barrar o epistemícidio.

Nesse sentido os últimos meses, ou no último ano, desde que ficou escancarado que não somos um país cordial, nem pacifico, desde que o estado de exceção se aprofundou e com ele a face autoritária nunca escondida, mas nem sempre tão explicita de nossa sociedade, são as mulheres negras que tem me encorajado a continuar refletindo sobre o mundo. Ao tomar contato com o feminismo negro, inicialmente com a Coleção Feminismos Plurais ${ }^{3}$, passei a perguntar também por que não estudamos em nossos cursos de graduação em Ciências Humanas e, especialmente, História, nem Sueli Carneiro, nem Lélia Gonzalez, nem Beatriz Nascimento, nem Ângela Davis, entre muitas, muitas outras. O quanto o que as feministas denominam de "colonização epistemológica" impediu nosso acesso a essas produções? Podemos, agora, estabelecer um lugar de escuta?

Certamente que para estabelecermos um lugar de escuta, precisamos entender e compreender os lugares de fala dessas autoras. Lélia Gonzalez diz que o "lugar que nos situamos determinará nossa interpretação sobre o duplo fenômeno do racismo e do sexismo" (Gonzalez, 1984, p. 224). "É necessário escutar por parte de quem sempre foi autorizado a falar" (Ribeiro, 2017, p.80). Mas o que é "lugar de fala"?

Djamila Ribeiro (2017) aponta para a origem imprecisa da expressão em si - já foi conceitualizada por profissionais da comunicação, mas também remete aos estudos

\footnotetext{
2 Vale questionar: "qual conhecimento está sendo reconhecido como tal? e qual conhecimento não o é? qual conhecimento tem feito parte das agendas acadêmicas? e qual conhecimento não? de quem é esse conhecimento? quem é reconhecida/o como alguém que possui conhecimento? e quem não o é? e quem pode ensinar conhecimento? e quem não pode? quem está no centro? e quem permanece fora?" (Kilomba, 2019, p.50).

3"O que é lugar de fala" de Djamila Ribeiro (2017); "O que é interseccionalidade" de Carla Akotirene (2018); "O que é racismo recreativo" de Adilson Moreira (2018); "O que é empoderamento" de Joice Berth (2018); "O que é encarceramento em massa" de Juliana Borges (2018); "Racismo estrutural" de Silvio Almeida (2018)
} 
arqueológicos/discursivos de Michel Foucault, aos estudos de Linda Alcoff (2016) e Gayatri Spivak (2010). No entanto, para Ribeiro parece mais pertinente trabalhar a partir da noção de "ponto de vista feminista", de Patricia Hill Collins (1997). Ribeiro diz que Collins propõe que se considere não a individualidade das experiências, mas a diversidade das experiências: "uma mulher negra terá experiências distintas de uma mulher branca por conta de sua localização social, vai experenciar gênero de uma outra forma" (Ribeiro, 2017, p. 63). Nesse sentido,

o falar não se restringe ao ato de emitir palavras, mas de poder existir. Pensamos lugar de fala como refutar a historiografia tradicional e a hierarquização dos saberes consequente da hierarquia social. Quando falamos de direito a existência digna, a voz, estamos falando de lócus social, de como esse lugar imposto dificulta a transcendência. Absolutamente não tem a ver com uma visão essencialista de que somente o negro pode falar sobre racismo, por exemplo. (Ribeiro, 2017, p. 66)

Logo, "lugar de fala" diz respeito a experiências comuns compartilhadas por um grupo de pessoas em meio às relações de poder. As experiências individuais importam na medida em que reverberam com o grupo, na medida em que dizem respeito às condições sociais de um grupo. Trata-se de uma análise estrutural que prioriza o lugar social que um grupo de pessoas ocupa, a partir de uma "matriz de dominação" (Ribeiro, 2017, p. 70), não perdendo de vista

o quanto raça, gênero, classe e sexualidade se entrecruzam gerando formas diferentes de experenciar opressões. Justamente por isso não pode haver hierarquia das opressões, pois, sendo estruturais, não existe 'preferência de luta' [...] Costumo brincar que não posso dizer que luto contra o racismo e amanhã, às $14 \mathrm{~h} 25$, se der tempo, eu luto contra o machismo, pois essas opressões agem de forma combinada. Sendo eu mulher negra, essas opressões me colocam em lugar de maior vulnerabilidade. Portanto, é preciso combatê-las de forma indissociável. (Ribeiro, 2017, p. 73)

Djamila Ribeiro pergunta, ainda: "dentro desse projeto de colonização quem foram as pessoas autorizadas a falar?” (2017, p. 79). Lélia Gonzalez talvez tenha sido uma das primeiras mulheres negras na academia que assumiu esse lugar com todos os seus riscos:

o risco que assumimos aqui é o ato de falar com todas as implicações. Exatamente por que temos sido falados, infantilizados (infans, é aquele que não tem fala própria, é a criança que se fala na terceira pessoa, porque falada pelos adultos), que nesse trabalho assumimos nossa própria fala. Ou seja, o lixo vai falar, e numa boa. (Gonzalez, 1984, p. 225)

As brancas começam a escutar Lélia. Quiçá, aprender com vocês a questionar/tensionar também nosso lugar privilegiado de branquitude, pois pensar lugar de fala é uma postura ética, como diz Djamila Ribeiro. A autora demonstra ainda que há uma diferença entre lugar de fala e representatividade que precisa ser sublinhado:

Uma travesti negra pode não se sentir representada por um homem branco cis, mas esse homem branco cis pode teorizar sobre a realidade das pessoas trans e travestis a partir do lugar que ele ocupa. Acreditamos que não pode haver essa desresponsabilização do sujeito do poder. A travesti negra fala a partir de sua localização, assim como o homem branco cis. (Ribeiro, 2017, p. 85-86)

Nesse caso, é a partir de minha localização - mulher branca, professora 
universitária - que teorizo sobre dispositivo da racialidade, epistemícidio e mulheres negras. A partir desse lugar que retomo minhas próprias experiências envolvendo minha mãe e Dona Leonor. E, por falar nela, talvez vocês queiram saber, como eu quis, depois do dia em que ouvi de minha mãe a frase racista que me colocou em contato com a vergonha, quem era dona Leonor. Quem era essa senhora que continuava nos visitando - e algumas vezes saía da casa de minha avó com pequenas sacolas contendo algo de alimentação e roupas. Foi o que perguntei a minha mãe que contou que minha avó dizia que ela tinha aparecido muito jovem na casa de minha bisavó e meu bisavô. Sua família tinha sido escravizada. Meus bisavós teriam consentido que ela ficasse morando com a família (certamente que em "troca" de trabalhos e cuidados com a casa e com os filhos, logo continuidade do trabalho escravo). Dona Leonor, ainda criança, dormia num banco na sala da casa e se cobria com uma pele de lã de ovelha. Morou lá até casar com seu Ayres. Quando casou, mudou para a casinha de paredes verdes, perto da família de minha mãe, e assim continuou frequentando a casa de minha avó.

Talvez essa vergonha guardada me leve a escrever hoje e retomar minhas lembranças de Dona Leonor. Vergonha por minha mãe, por mim, por Dona Leonor e sua família. Vergonha e reconhecimento desse dispositivo da racialidade que é estruturante em nossa sociedade. Essa seria uma forma de colocar "as tripas" ou as experiências no papel. "Mesmo se estivermos famintas, não somos pobres de experiências", diz Anzaldúa (2000, p. 235). Mesmo que não tenhamos um teto todo nosso - e aqui creio que a autora faz referência, nitidamente, às reflexões de Virginia Woolf em "Um teto todo seu" (2004) - precisamos escrever, colocar "nossas tripas no papel".

Convidada a escrever sobre mulheres e ficção, em 1928, após uma detalhada pesquisa sobre o tema, Virginia Woolf concluiu que as mulheres precisariam ter dinheiro e um teto todo seu, caso pretendessem se dedicar à escrita ficcional (2004, p. 08). Essas seriam condições mínimas necessárias, numa época em que nem frequentar bibliotecas desacompanhadas era permitido às mulheres. Em sua crítica, Woolf também tocou na questão da experiência, de forma irônica, mostrando como ela não cabia na escrita dos romancistas da época:

É um fato curioso como os romancistas têm um jeito de fazer-nos crer que os almoços são invariavelmente memoráveis por algo muito espirituoso que se disse ou muito sábio que se fez. Raramente, porém, reservam sequer uma palavra para o que se comeu. É consenso entre os romancistas não mencionar sopa, salmão e pato, como se sopa, salmão e pato não tivessem importância alguma, como se ninguém jamais tivesse fumado um charuto ou bebido um copo de vinho. Aqui, no entanto, tomarei a liberdade de desafiar esse consenso e de dizer-lhes que o almoço, nessa ocasião, começou com filés de linguado num prato fundo sobre o qual o cozinheiro da universidade espalhara uma cobertura do mais alvo creme, não fossem, aqui e ali, manchas castanhas como as dos flancos de uma corça [...] Nada de pressa, nada de brilhos, nada de ser alguém mais que si mesmo [...] Se, por sorte, tivesse havido à mão um cinzeiro, se, por falta dele, não se tivesse batido a cinza fora da janela, se as coisas tivessem sido um pouco diferentes do que foram, é provável que não se tivesse visto um gato sem rabo. (Woof, 2004, p. 15-16)

Virginia Woolf acreditava que apenas pessoas bem protegidas e "alimentadas" conseguiriam escrever. A metáfora gastronômica foi bastante utilizada por ela para demonstrar que as mulheres precisam de um mínimo de condições econômicas para poder escrever: "Sendo a estrutura humana o que é, coração, corpo e cérebro misturados, e não contidos em compartimentos separados [...] um bom jantar é de 
grande importância para a boa conversa [...] a lâmpada da espinha não acende com carne de vaca e ameixas secas" (2004, p. 23). Um bom jantar seria fundamental para uma boa escrita: um teto todo seu e condições financeiras favoráveis, pois que tempo e condições teria uma mulher que cuida da casa, dos filhos, que trabalha fora, ou nas plantações, que dorme apertada em casas de apenas um ou dois cômodos para escrever? Para colocar suas tripas no papel?

Quase sessenta anos mais tarde, na sua "Carta para as mulheres do terceiro mundo", para as mulheres de cor, Anzaldúa nos diz que mesmo que não tenhamos sopa, salmão nem pato, nem mesmo "carne de vaca e ameixas secas", mesmo se estivermos famintas e sem tempo e espaço, nossas experiências são comunicáveis. Possivelmente, apenas, não seja o gato sem rabo que esteja no papel, tampouco o pato ou o salmão.

Minhas queridas hermanas, os perigos que enfrentamos como mulheres de cor não são os mesmos das mulheres brancas, embora tenhamos muito em comum. Não temos muito a perder - nunca tivemos nenhum privilégio. [...] A mulher de cor iniciante é invisível no mundo dominante dos homens brancos e no mundo feminista das mulheres brancas, apesar de que, neste último, isto esteja gradualmente mudando. A lésbica de cor não é somente invisível, ela não existe. Nosso discurso também não é ouvido. Nós falamos em línguas, como os proscritos e os loucos. Porque os olhos brancos não querem nos conhecer, eles não se preocupam em aprender nossa língua, a língua que nos reflete, a nossa cultura, o nosso espírito. As escolas que frequentamos, ou não frequentamos, não nos ensinaram a escrever, nem nos deram a certeza de que estávamos corretas em usar nossa linguagem marcada pela classe e pela etnia. (Anzaldúa, 2000, p. 229)

Conceição Evaristo levou vinte anos para conseguir publicar uma de suas obras mais conhecidas: Becos da Memória. Seu discurso, sua língua, sua cultura narrados no romance, não foram ouvidos por duas décadas. Como Anzaldúa, Evaristo colocou ali suas tripas no papel, sua linguagem estava marcada pela classe e pela etnia. $A$ interseccionalidade das opressões compõe cada página do livro, e ela costuma dizer que perseguiu uma "escrevivência" ao produzir Becos da Memória:

Se a publicação de Becos da memória levou vinte anos para acontecer, o processo de escrita do livro foi rápido, muito rápido. Em poucos meses, minha memória ficcionalizou lembranças e esquecimentos de experiências que minha família e eu tínhamos vivido, um dia [...] Na base, no fundamento da narrativa de Becos está uma viviência, que foi minha e dos meus. Escrever Becos foi perseguir uma escrevivência. (Evaristo, 2017, p. 10-11)

É esse conceito ou noção de "escrevivências" que me interessa retomar aqui. Penso que a "escrita orgânica" de Anzaldúa se encontra perfeitamente com a noção de "escrevivências" de Conceição Evaristo. Entendo-as como uma escrita que privilegia a experiência. Aquela experiência que Walter Benjamin (1994) temia estar a caminho do fim, ao perceber que os combatentes da primeira guerra voltavam mudos, como que impossibilitados de comunicar uma experiência que teria excedido os limites da narração. Ou ainda, ao diagnosticar o declínio da narração - com o surgimento, entre outros, da imprensa e do romance moderno - em uma sociedade que ele aproximava do vidro: "um material tão duro e tão liso, no qual nada se fixa" (Benjamin, 1994, p. 117).

Didi-Huberman (2014) retoma as formulações de Walter Benjamin, ao dizer que o verbo utilizado por Benjamin sugeriria menos o fim da experiência, como muitos interpretaram, e mais um convite para retomarmos a dignidade, tanto da experiência, 
quanto da narração. Para Didi-Huberman, Benjamin dizia que "a experiência caminhava para seu fim", é essa caminhada que deve nos ocupar. Acredito que retomar os escritos, as propostas e os caminhos sugeridos pelos feminismos negros, questionar o dispositivo da racialidade e o epistemicídio, a colonialidade do saber-poder dominante, estabelecer um lugar de escuta, é privilegiar essa caminhada, contribuindo com o fortalecimento da experiência. Didi-Huberman diz ainda que "para conhecer os vaga-lumes, é preciso observá-los no presente de sua sobrevivência; é preciso vê-los dançar vivos no meio da noite, ainda que essa noite seja varrida por alguns ferozes projetores" (2014, p. 52). Esses projetores que negam e ofuscam a diferença, ignoram a interseccionalidade. Fortalecer a experiência é também buscar a episteme, os textos, os escritos - e as "escrevivências" - e as trajetórias das mulheres negras, mestiças, indígenas e tantas outras, que souberam e sabem dançar vivas no meio da noite, não se deixaram abater pelos projetores, inspirando e instigando-nos.

\section{Bibliografia}

AGAMBEN, Giorgio. Homo sacer: o poder soberano e a vida nua I. BH:UFMG, 2004.

ALCOFF, Linda Martín. Uma epistemologia para a próxima revolução. Revista Sociedade e Estado. Brasília, n. 1, v. 31, jan/abr. 2016. Disponível em: http://www.scielo.br/pdf/se/v31n1/0102-6992-se-31-01-00129.pdf. Acesso em 07/05/2019.

ANZALDÚA, Glória. Falando em línguas: uma carta para mulheres escritoras do terceiro mundo. Revista Estudos Feministas, ano 08, $1^{\circ}$ semestre 2000, p.229-236.

ANZALDÚA, Glória.La consciência de la mestiça/Rumo a uma nova consciência. Revista Estudos Feministas, 13(3):320, set-dez,2005, p. 704-719.

AKOTIRENE, Carla. O que é interseccionalidade. BH: Letramento/Justificando, 2018.

ALMEIDA, Silvio. O que é racismo estrutural. BH: Letramento/Justificando, 2018.

ARENDT, Hannah. Homens em tempos sombrios. Lisboa: Relógio d’Agua, 1991.

BENJAMIN, Walter. Magia e técnica, arte e política. SP: Brasiliense, 1994.

BERNARDINO-COSTA, J.; MALDONADO-TORRES, N.; GROSFOGUEL, R. (Orgs.). Decolonialidade e pensamento afrodiaspórico. BH: Autêntica, 2019.

BERTH, Joice. O que é empoderamento. BH: Letramento/Justificando, 2018.

BORGES, Juliana. O que é encarceramento em massa. BH: Letramento/Justificando, 2018.

CARNEIRO, Sueli Aparecida. A construção do outro como não-ser como fundamento do ser. Tese de Doutorado (Doutorado e Filosofia da Educação). São Paulo: Universidade de São Paulo, 2005.

COLLINS, Patrícia Hill. Comentário sobre o artigo de Hekman "Truth and Method: Feminist Standpoint Theory Revisited": Onde está o poder? Revista Sings, v. 22,n. 2, 1997, p. 375-381 [Tradução de Juliana Borges]

DIDI-HUBERMAN, Georges. Sobrevivência dos Vaga-lumes. BH: UFMG, 2011. 
EVARISTO, Conceição. Becos da Memória. RJ: Pallas, 2017.

FOUCAULT, Michel.História da Sexualidade vol.1.RJ: Graal, 2001.

FOUCAULT, Michel. O nascimento da biopolítica. SP: Martins Fontes, 2008.

GONZALEZ, Lélia. Racismo e sexismo na cultura brasileira. Revista Ciências Sociais Hoje, $\quad$ Anpocs, $1984 . \quad$ Disponível em:https://edisciplinas.usp.br/pluginfile.php/4584956/mod_resource/content $/ 1 / 06 \% 20$ \%20GONZALES\%2C\%20L\%C3\%A9lia\%20-\%20Racismo_e_Sexismo_na_Cultura_Br asileira\%20\%281\%29.pdf. Acesso em 10/05/2019.

KILOMBA, Grada. Memórias da Plantação: estudos de racismo cotidiano. SP: Cobogó, 2019.

MBEMBE, Achille. Necropolítica. SP: n-1edições, 2018.

MOREIRA, Adilson. O que é racismo recreativo. BH: Letramento/Justificando, 2018.

RIBEIRO, Djamila. O que é lugar de fala. BH: Letramento/Justificando, 2017.

WOOLF, Virginia. Um teto todo seu. RJ: Nova Fronteira, 2004.

RIOS, Flavia. RATTS, Alex. Lélia Gonzalez. Coleção Retratos do Brasil Negro. SP: Selo Negro, 2010.

ROSA, Susel Oliveira. A biopolítica e a vida que se pode deixar morrer. SP: Paco Editorial, 2012.

ROSA, Susel Oliveira. Fazer viver é deixar morrer. Revista Aulas, n.3, dez/2006 março/2007, p.1-14.

ROSA, Susel Oliveira e SILVA, Tatianne Ellen Cavalcante. O testemunho e as mulheres: Ophélia Amorim e Ediran Magalhães. In: ANDRADE, A.O., RIBEIRO, J.C., DINIZ, M.I., QUEIROZ, F.M. e SANTOS, L.P.M (orgs).Feminismo, gênero e sexualidade: diálogos contemporâneos. RN: UERN, 2016.

SPIVAK, Gayatri. Pode o subalterno falar? BH: UFMG, 2010.

\section{Notas de autoria}

Susel Oliveira da Rosa é professora do Departamento de História/Campus III/UEPB. Pós-Doutorado e Doutorado em História pela UNICAMP. Autora dos livros A biopolítica e a vida que se pode deixar morrer (SP: Paco Editorial, 2012) e Mulheres, ditaduras e memórias: não imagine que precise ser triste para ser militante (SP: Intermeios/Fapesp, 2013), atualmente é professora do Departamento de História da UEPB. Pesquisas em História do Brasil com ênfase no período da ditadura militar e enfoque nos temas: histórias de vida, violência, tortura, biopolítica, estado de exceção, mulheres, gênero, cuidado com o mundo e políticas da amizade. E-mail: susel.oliveira@gmail.com

\section{Como citar esse artigo de acordo com as normas da revista}

ROSA, Susel Oliveira da. "Não deixem a tinta coagular em suas canetas": por uma escrita orgânica. Sæculum - Revista de História, v. 24, n 41, p. 236-247, 2019. 
Contribuição de autoria

Não se aplica.

Consentimento de uso de imagem

Não se aplica.

Aprovação de comitê de ética em pesquisa

Não se aplica.

\section{Licença de uso}

Este artigo está licenciado sob a Licença Creative Commons CC-BY. Com essa licença você pode compartilhar, adaptar, criar para qualquer fim, desde que atribua a autoria da obra.

\section{Histórico}

Recebido em 25/08/2019.

Aprovado em 30/11/2019. 